\title{
Seed germination of the endangered Viola kitaibeliana and other Italian annual pansies (Viola Section Melanium, Violaceae)
}

\begin{abstract}
Magrini, S. \& Zucconi, L.: Seed germination of the endangered Viola kitaibeliana and other Italian annual pansies (Viola Section Melanium, Violaceae) [In Magrini, S. \& Salmeri, C. (eds), Mediterranean plant germination reports - 2]. F1. Medit. 30: 424-430. 2020. http://dx.doi.org/10.7320/FlMedit30.424

Here, successful germination protocols for the following four annual pansies are presented: Viola arvensis subsp. arvensis, $V$. hymettia, $V$. kitaibeliana, and $V$. tricolor subsp. tricolor. Seeds were collected mainly in Central Italy (Tuscany, Umbria, and Latium) and in Sicily. The germination ability was tested at the Tuscia Germplasm Bank (BGT) using several methods for dormancy-breaking. Our results show high germination percentages and germination rate for the tested species.
\end{abstract}

Key words: cold stratification, dormancy, priming, Viola arvensis, Viola hymettia, Viola tricolor.

\section{Introduction}

The Sect. Melanium DC. ex Ging. of the genus Viola (the so-called pansies) is a derived, monophyletic and morphologically well-defined group comprising 125 species, both perennials and annuals (Marcussen \& al. 2015). The genus is basically myrmecochorous but different selective pressures, especially seed predation, have produced a clear divergence in dispersal systems. Particularly, in the Sect. Melanium diplochory is exhibited by most species which have evolved a system combining ballistic and ant seed dispersal (Beattie \& Lyons 1975; Beattie 1985). Seeds are brown to dark brown (only immature ones are pale brown), ovoid to obovoid in shape, all with an elaiosome in the micropylar area and a conspicuous raphe (Scoppola \& Magrini 2019).

Pansy seeds have a physiological dormancy (Baskin \& Baskin 1995; 2014), so pretreatments for dormancy-breaking like cold stratification and/or hormones are required for germination. Elaiosome removal from seeds functions as a germination cue in many ant-dispersed plant species (e.g., Horvitz 1981; Blois \& Rockwood 1985; Lobstein \& Rockwood 1993; Ohkawara 2005). Elaiosome is also known to inhibit seed germination due to the presence of water-soluble inhibitory substances (Sasidharan \& Venkatesan 2019). On the other hand, its removal did not improve germination success in Viola striata Aiton (Lobstein \& Rockwood 1993), Viola pedata L. (Gehring \& al. 2013), and Viola pedunculata Torr. \& A. Gray. (Franklin \& al. 2017), so in our research elaiosomes were not removed from seeds. 
This paper is part of a larger research on the Sect. Melanium in Europe (e.g. Magrini \& Scoppola 2015a,b,c; Magrini 2019; Scoppola \& Magrini 2019). Particularly, research focused on germination ecology of annual pansies are carried out at the Tuscia Germplasm Bank (BGT) where seed accessions collected mainly in Central Italy are long term preserved. Here we present successful germination protocols of four closely related European pansies occurring in Italy: first data for $V$. kitaibeliana Schult. and $V$. hymettia Boiss. \& Heldr., and new data for Italy for Viola arvensis Murray subsp. arvensis and V. tricolor L. subsp. tricolor.

38. Viola arvensis Murray subsp. arvensis (Violaceae) (Fig. 1a)

\section{Accession data}

It: $\quad$ Tuscany. Sarteano (Siena), Mt. Cetona (WGS84: $42.931109^{\circ} \mathrm{N}, 11.875547^{\circ} \mathrm{E}$ ), edge of stony path on calcareous substrate, $1100 \mathrm{~m}$ a.s.1., 17 May 2012, A. Scoppola (BGT-A-29512, Tuscia Germplasm Bank).

It: Umbria. Norcia (Perugia), Forca d'Ancarano (WGS84: 42.819999 ${ }^{\circ} \mathrm{N}$, $\left.13.117497^{\circ} \mathrm{E}\right)$, margin of cultivated field, $1013 \mathrm{~m}$ a.s.1., 25 May 2012, A. Scoppola (BGT-A-29612, Tuscia Germplasm Bank).

It: Latium. Monte San Giovanni in Sabina (Rieti), Mt. Tancia (WGS84: $42.315850^{\circ} \mathrm{N}$ $12.744658^{\circ} \mathrm{E}$ ), stony grassland on calcareous soil, $1180 \mathrm{~m}$ a.s.1., 20 May 2014, $A$. Scoppola (BGT-A-28614, Tuscia Germplasm Bank).

It: Latium. Tivoli (Roma), Acque Albule (WGS84: $41.963056^{\circ} \mathrm{N}, 12.714722^{\circ} \mathrm{E}$ ), dry grassland on a travertine outcrop, $66 \mathrm{~m}$ a.s.1., 20 May 2014, S. Magrini (BGT-A28913, Tuscia Germplasm Bank).

\section{Germination data}

Pre-treatments: sterilization with a solution of 5\% sodium hypochlorite + Tween 20 for 5 minutes, followed by 3 rinses in sterile distilled water. Cold-moist stratification for 1 month at $5^{\circ} \mathrm{C}$.

Germination medium: $1 \%$ agar $+250 \mathrm{mg} / \mathrm{GA}_{3}$.

Sample size: 100 seeds for each test $(20 \times 5$ replicates $)$.

\begin{tabular}{cccccccc}
\hline Germination & Thermoperiod & $\begin{array}{c}\text { Photoperiod } \\
{[\text { light/dark] }}\end{array}$ & $\begin{array}{c}\mathbf{T}_{\mathbf{1}} \\
{[\mathbf{d}]}\end{array}$ & $\begin{array}{c}\mathbf{T}_{\mathbf{5} 0} \\
{[\mathbf{d}]}\end{array}$ & $\begin{array}{c}\mathbf{T}_{\max } \\
{[\mathbf{d}]}\end{array}$ & $\begin{array}{c}\text { MTG } \\
{[\mathbf{d}]}\end{array}$ & $\begin{array}{c}\text { Accession } \\
\text { code }\end{array}$ \\
\hline $\mathbf{1 0 0 \%}$ & constant $20^{\circ} \mathrm{C}$ & $12 / 12 \mathrm{~h}$ & 6.0 & 12.2 & 24.0 & 12.3 & BGT-A-28614 \\
\hline $\mathbf{1 0 0} \%$ & constant $20^{\circ} \mathrm{C}$ & $12 / 12 \mathrm{~h}$ & 7.0 & 10.6 & 30.0 & 17.3 & BGT-A-29512 \\
\hline $\mathbf{1 0 0} \%$ & constant $20^{\circ} \mathrm{C}$ & $12 / 12 \mathrm{~h}$ & 8.6 & 13.6 & 21.3 & 14.3 & BGT-A-29612 \\
\hline $\mathbf{9 5 . 2 \%}$ & constant $20^{\circ} \mathrm{C}$ & $12 / 12 \mathrm{~h}$ & 5.0 & 9.6 & 21.7 & 11.3 & BGT-A-28913 \\
\hline
\end{tabular}

\section{Observations}

Viola arvensis subsp. arvensis (field pansy) is a Mediterranean-Eurasiatic winter annual pansy widespread throughout Europe and SW Asia as a weed in cultivated 
fields, in synanthropic habitats, and open shrublands (Scoppola \& Magrini 2019).

Germination tests were carried out with or without cold stratification. The effect of both hydro- and hormo-priming was tested, soaking seeds, respectively, in distilled water and in a solution of gibberellic acid $(250 \mathrm{mg} / \mathrm{l})$ for $24 \mathrm{~h}$ at $20^{\circ} \mathrm{C}$ in darkness. Seeds were sown on water-agar with or without the addition of gibberellic acid. No germination was recorded without cold stratification nor for primed seeds, contrarily to results for hydro-priming (ca. 40\%) reported by Rajabalipour \& al. (2013). High germination $(>95 \%)$ was obtained at $20^{\circ} \mathrm{C}$ only with the combination of both cold stratification and the addition of $\mathrm{GA}_{3}$ to the substrate, in accordance with results reported by Royal Botanic Gardens Kew (2020). Moreover, seeds were sorted into two colour fractions, pale (immature) and dark brown (mature), to assess seed maturity effect on germination. Both germination percentage and rate were higher for dark than pale brown seeds $\left(100 \%\right.$ vs $6.7 \%$ and $\mathrm{T}_{50}: 9.9$ vs 20.0 , respectively), confirming that seed maturity also affects $V$. arvensis seed germination, as reported for $V$. wittrockiana Gams (Agnieszka \& Holubowicz 2008).

39. Viola hymettia Boiss. \& Heldr. (Violaceae)

\section{Accession data}

It: $\quad$ Latium. Viterbo (Viterbo), loc. Asinello (WGS84: $42.401150^{\circ} \mathrm{N}, 12.072031^{\circ} \mathrm{E}$ ), dry grassland on volcanic soil, 276 m a.s.1., 18 Apr 2018, L. Cracco (BGT-A-48318, Tuscia Germplasm Bank).

Si: $\quad$ Piazza Armerina (Enna), Cannarozzo (WGS84: $37.409167^{\circ} \mathrm{N}, 14.380556^{\circ} \mathrm{E}$ ), clearing in a pine forest, $730 \mathrm{~m}$ a.s.1., 21 Mar 2019, R. Galesi (BGT-A-68619, Tuscia Germplasm Bank).

\section{Germination data}

Pre-treatments: sterilization with a solution of 5\% sodium hypochlorite + Tween 20 for 5 minutes followed by 3 rinses in sterile distilled water.

Germination medium: 1\% agar $+250 \mathrm{mg} / \mathrm{lGA}_{3}$.

Sample size: 100 seeds for each test $(20 \times 5$ replicates $)$.

\begin{tabular}{cccccccc}
\hline Germination & Thermoperiod & $\begin{array}{c}\text { Photoperiod } \\
{[\text { light/dark] }}\end{array}$ & $\begin{array}{c}\mathbf{T}_{\mathbf{1}} \\
{[\mathbf{d}]}\end{array}$ & $\begin{array}{c}\mathbf{T}_{\mathbf{5 0}} \\
{[\mathbf{d}]}\end{array}$ & $\begin{array}{c}\mathbf{T}_{\max } \\
{[\mathbf{d}]}\end{array}$ & $\begin{array}{c}\text { MTG } \\
{[\mathbf{d}]}\end{array}$ & Accession code \\
\hline $\mathbf{8 8 . 7 \%}$ & constant $15^{\circ} \mathrm{C}$ & $12 / 12 \mathrm{~h}$ & 6.8 & 12.4 & 22.3 & 13.1 & BGT-A-48318 \\
\hline $\mathbf{8 4 . 9 \%}$ & constant $15^{\circ} \mathrm{C}$ & $12 / 12 \mathrm{~h}$ & 6.0 & 8.8 & 24.3 & 11.7 & BGT-A-68619 \\
\hline
\end{tabular}

\section{Observations}

Viola hymettia is an annual pansy widespread in the southern Balkans and the Aegean Islands, quite rare in central and southern Italy and Sicily, linked to stony pas- 
tures, dry open habitats and shrub fringes, mostly on sub-acid soils (Scoppola \& Magrini 2019).

Here we report the first germination data for Viola hymettia. Cold stratification was not required in accordance with results for $V$. calaminaria (Ging.) Lej. (Godefroid \& Van de Vyver 2020). The effect of both hydro- and hormo-priming was tested, soaking seeds, respectively, in distilled water and in a solution of gibberellic acid $(250 \mathrm{mg} / \mathrm{l})$ for $24 \mathrm{~h}$ at $20^{\circ} \mathrm{C}$ in darkness and sowing them on water-agar medium. Not primed seeds were sown on water-agar with the addition of gibberellic acid $(250 \mathrm{mg} / \mathrm{l})$. High germination $(>84 \%)$ was obtained at $15^{\circ} \mathrm{C}$ only for not primed seeds on the substrate with the addition of $\mathrm{GA}_{3}$. Very low germination was recorded for both hydro- and hormo-primed seeds of all the tested accessions (0-2\% and 8-9\%, respectively).

40. Viola kitaibeliana Schult. (Violaceae) (Fig. 1b)

\section{Accession data}

It: Latium. Nespolo (Rieti), Cerreta (WGS84: $\left.42.162784^{\circ} \mathrm{N} 13.080031 \mathrm{E}\right)$, open grassland on calcareous soil, $1000 \mathrm{~m}$ a.s.1., 16 Jun 2010, A. Scoppola (BGT-A-14710, Tuscia Germplasm Bank).

It: Latium. Varco Sabino (Rieti), Mt. Navegna (WGS84: $42.234799^{\circ} \mathrm{N} 12.992089^{\circ} \mathrm{E}$ ), stony grassland on calcareous soil, 1184 m a.s.1., 2 Jun 2014, A. Scoppola (BGT-A28714, Tuscia Germplasm Bank).

It: Umbria. Norcia (Perugia), Forca d'Ancarano (WGS84: $42.819651^{\circ} \mathrm{N}$ $\left.13.117618^{\circ} \mathrm{E}\right)$, stony meadow between fields on calcareous soil, $1010 \mathrm{~m}$ a.s.1., 11 May 2012, A. Scoppola (BGT-A-29712, Tuscia Germplasm Bank).

\section{Germination data}

Pre-treatments: sterilization with a solution of 5\% sodium hypochlorite + Tween 20 for 5 minutes followed by 3 rinses in sterile distilled water.

Germination medium: 1\% agar + 1) $250 \mathrm{mg} / 1 \mathrm{GA}_{3}$ and 2) $500 \mathrm{mg} / 1 \mathrm{GA}_{3}$.

Sample size: 100 seeds for each test $(20 \times 5$ replicates $)$.

\begin{tabular}{cccccccc}
\hline \multirow{2}{*}{ Germination } & \multirow{2}{*}{ Thermoperiod } & $\begin{array}{c}\text { Photoperiod } \\
{[\text { light/dark] }}\end{array}$ & $\begin{array}{c}\mathbf{T}_{\mathbf{1}} \\
{[\mathbf{d}]}\end{array}$ & $\begin{array}{c}\mathbf{T}_{\mathbf{5 0}} \\
{[\mathbf{d}]}\end{array}$ & $\begin{array}{c}\mathbf{T}_{\max } \\
{[\mathbf{d}]}\end{array}$ & $\begin{array}{c}\text { MTG } \\
{[\mathbf{d}]}\end{array}$ & Accession code \\
\hline $\mathbf{1 0 0 \%}^{\mathbf{1}}$ & constant $20^{\circ} \mathrm{C}$ & $12 / 12 \mathrm{~h}$ & 6.0 & 12.2 & 19.0 & 12.3 & BGT-A-28714 \\
\hline $\mathbf{1 0 0 \%}^{\mathbf{2}}$ & constant $20^{\circ} \mathrm{C}$ & $12 / 12 \mathrm{~h}$ & 8.0 & 11.7 & 17.3 & 12.1 & BGT-A-14710 \\
\hline $\mathbf{9 3 . 3 \%}^{\mathbf{1}}$ & constant $20^{\circ} \mathrm{C}$ & $12 / 12 \mathrm{~h}$ & 7.0 & 11.6 & 21.7 & 12.2 & BGT-A-14710 \\
\hline $\mathbf{8 0 . 3 \%}{ }^{1}$ & constant $20^{\circ} \mathrm{C}$ & $12 / 12 \mathrm{~h}$ & 6.0 & 5.8 & 24.7 & 9.8 & BGT-A-29712 \\
\hline
\end{tabular}

\section{Observations}

Viola kitaibeliana is a winter annual small-flowered pansy extremely rare in Europe where it is a component of early stages of grasslands, stony slopes, and other open places 
(Randal 2004; Magrini \& Scoppola 2015a, 2015b). In particular, it has a highly fragmented distribution in Italy, where it is endangered. Here we report the first germination data for this species.

Germination tests were carried out after 0 and 1 month of cold stratification at $5^{\circ} \mathrm{C}$. Seeds were sown on water-agar with the addition of gibberellic acid. No germination was recorded without cold stratification. High germination $(>80 \%)$ was obtained at $20^{\circ} \mathrm{C}$ only with the combination of both cold stratification and the addition of $\mathrm{GA}_{3}$ to the substrate.

\section{Viola tricolor L. subsp. tricolor (Violaceae)}

\section{Accession data}

It: Latium. Vejano (Viterbo), loc. Acquaforte (WGS84: $42.218919^{\circ} \mathrm{N} 12.110024^{\circ} \mathrm{E}$ ), shrubby grassland, 353 m a.s.1., 14 May 2017, S. Buono (BGT-A-41517, Tuscia Germplasm Bank).

\section{Germination data}

Pre-treatments: sterilization with a solution of 5\% sodium hypochlorite + Tween 20 for 5 minutes followed by 3 rinses in sterile distilled water.

Germination medium: 1\% agar $+250 \mathrm{mg} / \mathrm{lGA}_{3}$.

Sample size: 100 seeds for each test $(20 \times 5$ replicates $)$.

\begin{tabular}{ccccccc}
\hline Germination & Thermoperiod & $\begin{array}{c}\text { Photoperiod } \\
\text { [light/dark] }\end{array}$ & $\mathbf{T}_{\mathbf{1}}[\mathbf{d}]$ & $\mathbf{T}_{\mathbf{5 0}}[\mathbf{d}]$ & $\begin{array}{c}\mathbf{T}_{\max } \\
{[\mathbf{d}]}\end{array}$ & $\begin{array}{c}\text { MTG } \\
{[\mathbf{d}]}\end{array}$ \\
\hline $\mathbf{8 3 . 1 \%}$ & constant $15^{\circ} \mathrm{C}$ & $12 / 12 \mathrm{~h}$ & 7.0 & 13.3 & 24.5 & 13.6 \\
\hline
\end{tabular}
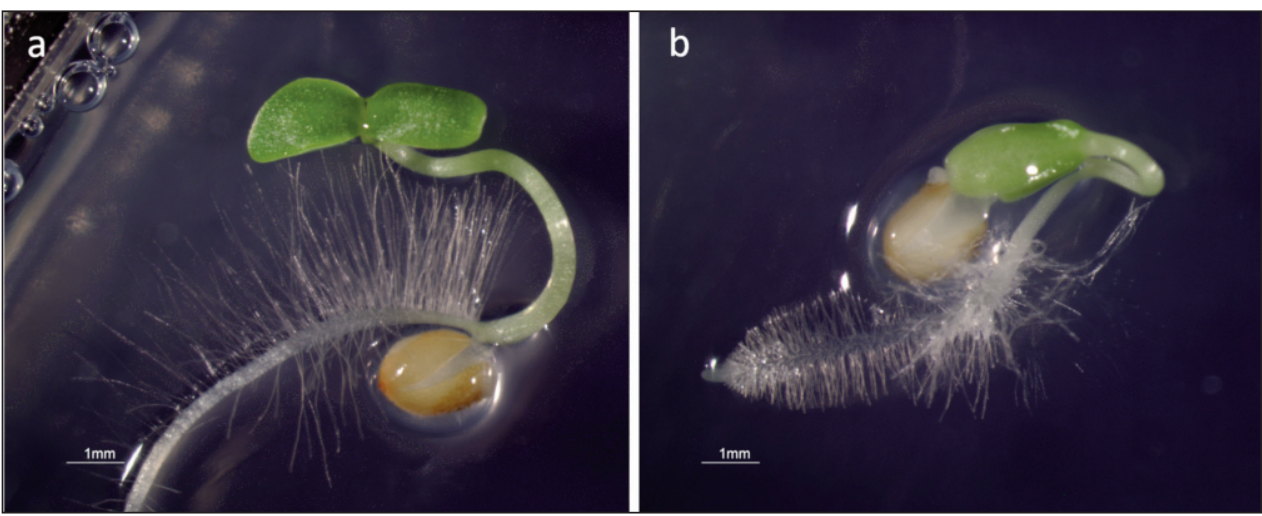

Fig. 1. Germinated seeds of: a, Viola arvensis subsp. arvensis and b, V. kitaibeliana. 


\section{Observations}

Viola tricolor subsp. tricolor is a pansy occurring in habitats linked to woodlands and semi-natural lands in south Europe (Scoppola \& Magrini 2019).

Following Godefroid \& Van de Vyver (2020), cold stratification was not required. The effect of both hydro- and hormo-priming was tested, soaking seeds, respectively, in distilled water and in a solution of gibberellic acid $(250 \mathrm{mg} / \mathrm{l})$ for $24 \mathrm{~h}$ at $20^{\circ} \mathrm{C}$ in darkness and sowing them on water-agar medium. Not primed seeds were sown on water-agar with the addition of gibberellic acid. High germination $(>83 \%)$ was obtained at $15^{\circ} \mathrm{C}$ only for not primed seeds on the substrate with the addition of $\mathrm{GA}_{3}$, in accordance with results reported by Royal Botanic Gardens Kew (2020). Lower germination was recorded for both hydro- and hormo-primed seeds ( $4 \%$ and $16 \%$, respectively).

\section{Acknowledgement}

The authors thank R. Galesi and A. Cristaudo for collecting seeds of Viola hymettia in Sicily.

\section{References}

Agnieszka, R., \& Holubowicz, R. 2008: Effect of pansy (Viola x wittrockiana Gams) seeds colour and size on their germination. - Not. Bot. Hort. Agrobot. Cluj-Napoca 36(2): 47-50. http://dx.doi.org/10.15835/nbha36267

Baskin, C. C. \& Baskin, J. M. 2014: Seeds. Ecology, Biogeography, and Evolution of Dormancy and Germination. $2^{\text {nd }}$ Edition. Academic Press - San Diego, CA, USA.

Baskin, J. M. \& Baskin, C. C. 1995: Variation in the annual dormancy cycle in buried seeds of the weedy winter annual Viola arvensis. - Weed Res. 35: 353-362. http://dx.doi.org/10.1111/j.1365-3180.1995.tb01630.x

Beattie, A. J. 1985: The evolutionary ecology of ant-plant mutualism. - Cambridge.

— \& Lyons, N. 1975: Seed dispersal in Viola (Violaceae): adaptations and strategies. - Amer. J. Bot. 62(7): 714-722. http://dx.doi.org/10.1002/j.1537-2197.1975.tb14104.x

Blois M. C. \& Rockwood L. L. 1985: Effect of elaiosome removal on germination in ant-dispersed plant. - Virginia J. Sci. 36: 118.

Franklin, S., Tran, L. B., Farzad, D. \& Hill. R. I. 2017: Seed Germination in Viola pedunculata and Viola purpurea subsp. quercetorum (Violaceae), critical food plants for two rare butterflies. Madroño 64(1): 43-50. http://dx.doi.org/10.3120/0024-9637-64.1.43

Gehring, J. L., Cusac, T., Shaw, C. \& Timian, A. 2013: Seed germination of Viola pedata, a key larval host of a rare butterfly. - Native Pl. J. 14(3): 205-212. http://dx.doi.org/10.3368/npj.14.3.205

Godefroid, S. \& Van de Vyver, A. 2020: Seed germination ecology of Viola calaminaria, an endangered metallophyte with a narrow distribution. - Pl. Species Biol. 35: 89-96. http://dx.doi.org/10.1111/1442-1984.12259

Horvitz, C. C. 1981: Analysis of how ant behaviors affect germination in a tropical myrmecochore, Calathea microcephala (P. \& E.) Koernicke (Marantaceae): microsite selection and aril removal by neotropical ants: Odontomachus, Pachycondyla and Solenopsis (Formicidae). Oecologia 51: 47-52. http://dx.doi.org/10.1007/BF00344651

Lobstein, M. B. \& Rockwood, L. L. 1993: Influence of elaiosome removal on germination in five ant-dispersed plant species. - Virginia J. Sci. 44: 59-71.

Magrini, S. 2019: Typification of Iberian names in Viola Sect. Melanium (Violaceae) with nomenclatural notes. - Phytotaxa 399(2): 147-159. https://doi.org/10.11646/phytotaxa.399.2.4 
— \& Scoppola, A. 2015a: Cytological status of Viola kitaibeliana Schult. in Europe. - Phytotaxa 238(3): 288-292. http://dx.doi.org/10.11646/phytotaxa.238.3.9

— \& - 2015b: Further studies in Viola Sect. Melanium (Violaceae). Identity and typification of Viola nana and $V$. henriquesii, two neglected European Atlantic taxa. - Phytotaxa 230(3): 259266. http://dx.doi.org/10.11646/phytotaxa.230.3.4

— \& - 2015c: Variability of pollen aperture heteromorphism in annual pansies (Viola Section Melanium). - Acta Bot. Croat. 74(1): 43-52. doi: 10.1515/botcro-2015-0003

Marcussen, T., Heier, L., Brysting, A. K., Oxelman, B. \& Jakobsen, K. S. 2015: From gene trees to a dated allopolyploid network: insights from the angiosperm genus Viola (Violaceae). - Syst. Biol. 64(1): 84-101. http://dx.doi.org/10.1093/sysbio/syu071

Ohkawara, K. 2005: Effect of timing of elaiosome removal on seed germination in the ant-dispersed plant, Erythronium japonicum (Liliaceae). - Pl. Species Biol. 20: 145-148. http://dx.doi.org/ 10.1111/j.1442-1984.2005.00133.x

Rajabalipour, F., Zade, A. A. \& Bakhtiari, S. 2013: Effect of priming solution, concentration and duration on pansy (Viola tricolor L. var. arvensis) seed germination and vegetative parameters. Intl. J. Agron. Plant Prod. 4(12): 3262-3266.

Randall, R. E. 2004: Biological flora of the British Isles no. 233: Viola kitaibeliana Schult(es). - J. Ecol. 92(2): 361-369. http://dx.doi.org/10.1111/j.0022-0477.2004.00877.x

Royal Botanic Gardens Kew 2020: Seed Information Database (SID). Version 7.1. Available from: http://data.kew.org/sid/ [Last accessed 06/10/2020].

Sasidharan, R. \& Venkatesan, R. 2019: Seed elaiosome mediates dispersal by ants and impacts germination in Ricinus communis. - Front. Ecol. Evol. 7: 246. http://dx.doi.org/10.3389/fevo.2019.00246

Scoppola, A. \& Magrini, S. 2019: Comparative palynology and seed morphology in annual pansies (Viola Sect. Melanium, Violaceae): implications for species delimitation. - Pl. Biosyst. 153(6): 883-899. http://dx.doi.org/10.1080/11263504.2019.1610113

Addresses of the authors:

Sara Magrini ${ }^{1 *} \&$ Laura Zucconi ${ }^{1,2}$,

${ }^{1}$ Tuscia Germplasm Bank, Tuscia University, Viterbo, Italy. E-mail: magrini@unitus.it

${ }^{2}$ Department of Ecological and Biological Sciences, Tuscia University, Viterbo, Italy.

E-mail: zucconi@unitus.it

*corresponding author 